\title{
In vivo Study of Tetraprenyltoluquinone, An Anticancer Compounds from Garcinia cowa Roxb
}

\author{
Fatma Sri Wahyuni ${ }^{*}$, Lim Siang Hui ${ }^{2}$, Johnson Stanslas ${ }^{3}$, Nordin Hj Lajis ${ }^{4}$ and Dachriyanus ${ }^{1}$ \\ 'Faculty of Pharmacy, Andalas University, Kampus Limau Manis, Padang, West Sumatra, INDONESIA. \\ ${ }^{2}$ CARIF (Cancer Research Institute Foundation) MALAYSIA. \\ ${ }^{3}$ Faculty of Medicine and Health Sciences, Universiti Putra Malaysia 43400 UPM, Serdang, Selangor, MALAYSIA \\ ${ }^{4}$ Laboratory of Natural Products, Institut of Bioscience, Universiti Putra Malaysia, 43400 UPM, Serdang, Selangor, MALAYSIA.
}

\begin{abstract}
Objective: To investigate the in vivo antitumor effect of TPTQ against $\mathrm{H}-460$ lung cancer cell lines in nude mice. Materials and Methods: Female nude mice bearing $\mathrm{H}-460$ tumor at size approximately $5 \mathrm{~mm}$ in diameter were treated with a single intraperitoneal dose $800 \mathrm{mg} / \mathrm{kg}$ of TPTQ. The vehicletreated (10\% tween 80$)$ animals were used as control group. The tumor size and mice body weight were measured for 14 days. Results: Single treatment of $800 \mathrm{mg} / \mathrm{kg}$ of TPTQ displayed moderate antitumor activity against $\mathrm{H}-460$ tumor xenografts as compared with vehicle-treated control. The mean time to reach RTV of 4 for vehicle-treated control group was 4.5 days whereas for TPTQ-treated $(800 \mathrm{mg} / \mathrm{kg}$ ) group was 9.5 days. Conclusion: The results showed that TPTQ slowed the tumor growth by 5 days. Thus, TPTQ may be considered as a promising compound in cancer chemotherapy
\end{abstract}

Key words: Tetrapreniltoluquinone, Lung cancer, Nude mice, H-460, Xenografts.

\section{Correspondence :}

Fatma Sri Wahyuni,

Faculty of Pharmacy, Andalas University,

Kampus Limau Manis, Padang,

West Sumatra, INDONESIA.

Phone no: +6275171682

Email: fatmasriwahyuni@gmail.com

DOI: 10.5530/jyp.2017.9.58

\section{INTRODUCTION}

Lung cancer is known to be the most frequent cancer worldwide and the incidence of this epidemic disease is continuing to increase at $0.5 \%$ per year globally. ${ }^{1}$ There were 1.82 and 1.59 million new lung cancer cases and deaths worldwide, respectively. ${ }^{2,3}$ However, significant progress is underway in both the prevention and treatment of lung cancer. ${ }^{3}$

The development of new therapeutic approach to breast cancer remains one of the most challenging area in cancer research. Many tropical plants have interesting biological activities with potential therapeutic applications. ${ }^{4}$ Garcinia cowa Roxb, family Guttiferae, is named 'kandis' can be found in the tropical rainforest such as Indonesia, Malaysia, Philippines and Thailand. ${ }^{5}$

Many parts of G. cowa have been used in traditional folk medicine. The bark, latex and root have been used as an antifever agent ${ }^{6}$ while the fruit and leaves have been used for indigestion and improvement of blood circulation, and as an expectorant. ${ }^{7}$ The chemical composition and biological activities of various parts of $G$. cowa have been investigated. ${ }^{8}$

In the previous paper, we have reported cytotoxicity study of ethanol extract ${ }^{9}$ and cytotoxic xanthones from the stem bark of G. cowa. ${ }^{10}$ A new ring reduced prenyltoluquinone, Tetraprenyltoluquinone (TPTQ) (Figure 1) was first isolated for G. cowa. ${ }^{11}$ This compound was inhibited the small lung cancer cell $\mathrm{H}_{460}{ }^{12}$ by inducing cell cycle arrest at $\mathrm{G} 1$ phase. ${ }^{13}$ In this paper, the ability of this compound in inhibiting tumor growth in a nude mice xenograft model was reported.

\section{MATERIALS AND METHODS}

Materials

TPTQ was isolated from G. cowa. H-460 cell line was purchased from the American Type Culture Collection (Manassas, VA, USA). The cancer cells were cultured in RPMI 1640 medium (Life Technologies, Paisly, UK) with $10 \% \mathrm{v} / \mathrm{v}$ fetal calf serum (PAA Laboratories, Linz, Austria), $100 \mathrm{IU} / \mathrm{mL}$ penicillin and $100 \mu \mathrm{g} / \mathrm{mL}$ streptomycin (Life Technologies, Paisly, UK) whereas the RAW 264.7 cells were grown in Dulbecco's Modified Eagle's Medium (DMEM) (Life Technologies, Paisly, UK) with phenol red containing HEPES, L-glutamine supplemented with $10 \%$ fetal bovine serum (FBS) and 1\% antibiotic/antimycotic solution trypsin-EDTA were purchased from GIBCO (Auckland, New Zealand). Phosphate buffered saline (PBS) tablets, propidium iodide, ribonuclease A (RNase A), bovine serum albumin (fraction V) were obtained from Sigma Chemicals (St. Louis, USA). Tween-20 was purchased from Merck (Hohenbrunn, Germany). Dimethylsulfoxide (DMSO) was purchased from BDH Laboratory (England) and 3-(4,5dimethylthiazol-2yl)diphenyltetrazolium bromide (MTT) from Phytotechnology Laboratories (Kansas, USA). Culture flask $\left(25 \mathrm{~cm}^{2}\right.$ and $\left.75 \mathrm{~cm}^{2}\right)$, 96-well plates and $10 \mathrm{ml}$ serological pipettes were purchased from Becton Dickson (New Jersey, USA).

\section{Instruments}

Holten laminar airflow microbiological safety cabinet class II was obtained from Heto-Holten (Allerød, Denmark), and Galaxy ${ }^{\oplus} \mathrm{CO}_{2}$ incubator was purchased from RS Biotech (Ayrshire, Scotland). A micro plate reader equipped SOFTmax ${ }^{\curvearrowleft}$ Prosoftware (Versamax, Molecular Devices, California, and USA) was used to measure of the formazan solution. 
FACSscan flow cytometry (Becton Dickinson, Sunnyale, CA) was used in cell cycle analysis.

\section{Cell Culture}

All cell lines were maintained in RPMI 1640 culture medium, supplemented with $10 \%$ heat-inactivated FBS, $100 \mathrm{U} / \mathrm{ml}$ penicillin and $100 \mu \mathrm{g} / \mathrm{ml}$ streptomycin. Cells were grown in $25 \mathrm{~cm} 2$ tissue culture flasks in a humidified atmosphere containing $5 \% \mathrm{CO} 2$ at $37^{\circ} \mathrm{C}$. Once the cells reach $80 \%$ confluence, $1 \mathrm{ml}$ of trypsin-EDTA solution was added to the flask for 5-10 min to detach the monolayer cells. The cells were occasionally observed under the inverted microscope until the cell layer was dispersed. Then, $3 \mathrm{ml}$ of complete growth medium was added to the flask followed by repeated gentle pipetting to split apart the cell clumps. Approximately $0.5-1 \times 10^{6}$ cells were sub cultured into a new $25 \mathrm{~cm}^{2}$ flask containing $8 \mathrm{ml}$ of fresh medium.

\section{Animal experiments}

Homozygous $n u / n u$ athymic mice aged between 6-8 weeks old were provided by the Laboratory Animal Resource Unit, Institute for Medical Research, Kuala Lumpur. The mice were housed in sterile individually ventilated seal safe TM cages. These cages will be maintained under pathogen-limiting conditions. Temperature in the husbandry was kept at $27^{\circ} \mathrm{C}$. Mice were maintained in a quiet, isolated and controlled environment with a uniform light-dark cycle of $12 \mathrm{hr}$ of light and $12 \mathrm{hr}$ of dark. Pellets were commercially obtained from Specialty Feeds (Glen Forrest, Australia) and water was autoclaved and provided in excess. Gloves and utensils were sterilized with alcohol between handling of the animal. Ethical clearance was obtained from the Malaysian Ministry of Health with the reference number of ACUC/KKM/02(3/2004). All experiments were done according to the protocols approved by Animal Care and Use Committee (ACUC) of Faculy of Medicine and Health Sciences, Universiti Putra Malaysia with reference number UPM/FPSK/PADS/ BR/UUH/00145.

\section{Maximum Tolerated Dose (MTD)}

Determination of MTD is important prior to starting an experiment in order to avoid possibility of excessive dosage, which may lead to severe toxicity in the experimental animals. To determine the maximum tolerated dose (MTD) of lead compound (TPTQ), a simple sub acute toxicity test was carried out. The rats were subjected to treatment according to selected doses at $100 \mathrm{mg} / \mathrm{kg}, 200 \mathrm{mg} / \mathrm{kg}, 400 \mathrm{mg} / \mathrm{kg}, 600 \mathrm{mg} / \mathrm{kg}, 800 \mathrm{mg} / \mathrm{kg}$ and $1000 \mathrm{mg} / \mathrm{kg}$ of TPTQ, $10 \% \mathrm{w} / \mathrm{v}$ tween 80 was used as vehicle. Each rat was given a single dose (i.p.) of TPTQ followed by 14 days observation. The parameter of the weight loss was observed as an indicator of toxicity. Upon obtaining the MTD, dose lower than the MTD were selected for the in vivo anti tumor study of TPTQ.

\section{In vivo Antitumoral Assay}

Seven athymic female BALB/c nu/nu mice aged 6-8 weeks, weighing 20-26 g were used in this study. The animals were housed in individually ventilated cages under specific pathogen-free (SPF) condition throughout the experiment. Each cage contained 1-2 mice and the animals were given free access to chow and sterilized distilled water. All animals were maintained in a hygienic environment under controlled temperature $\left(24^{\circ} \mathrm{C}\right)$. Viable H-460 cells at size of $5 \times 10^{6}$ cells at exponential growth phase in $0.1 \mathrm{ml}$ were implanted subcutaneously into the right flank in $0.1 \mathrm{ml}$ RPMI 1640 medium. The implanted animals were observed twice weekly for tumor appearance. Once tumors had reached a measurable size of $17 \mathrm{~mm}$, the tumors were harvested from the animals. Then, tumors were excised from donor animals, placed in sterile physiological saline containing antibiotics and cut into small fragments of approximately $2 \mathrm{~mm}^{3}$. Under brief diethyl ether anesthesia, a single fragment was implanted subcutaneously into the flank of each mouse using a trocar.
This process was repeated for three passages in order to ensure a good take rate of the tumors in nude mice. Once the tumor growth reached approximately $5 \mathrm{~mm}$ in diameter (denoted as day 0 ), the mice were allocated into groups of by restricted randomization to keep group mean tumor size variation to a minimum. Treatment with TPTQ at a single dose of $800 \mathrm{mg} / \mathrm{kg}$ in $10 \%$ Tween 80 (through intraperitoneal injection) for fourteen days. Concurrently, the normal control group was treated with $10 \%$ Tween 80 (i.p). The treatment period was for 14 days. The tumor size and body weights after TPTQ administration were measured and recorded for a total period of 14 days. The body weight data obtained was then converted to percentage body weight changes. The length and width of tumors were measured and the volume (v) was calculated using the formula $\mathrm{v}=(\text { width })^{2} \times($ length $/ 2) .{ }^{14}$ Percentage tumor growth was calculated as $\mathrm{T} / \mathrm{C}$ by the following formula:

$\mathrm{T} / \mathrm{C}=\left(\mathrm{T}_{\mathrm{n}}-\mathrm{T}_{\mathrm{o}} / \mathrm{C}_{\mathrm{n}}-\mathrm{C}_{\mathrm{o}}\right) \times 100$

If $\left(\mathrm{T}_{\mathrm{n}}-\mathrm{T}_{\mathrm{o}}\right)<0$, then $\mathrm{T} / \mathrm{C}=\left(\mathrm{T}_{\mathrm{n}}-\mathrm{T}_{\mathrm{o}}\right) / \mathrm{T}_{\mathrm{o}} \times 100$

$\mathrm{C}_{\mathrm{o}}\left(\mathrm{C}_{\mathrm{n}}\right)$ : Tumor weight of day 0 (day $\mathrm{n}$ ) in the control group

$\mathrm{T}_{\mathrm{o}}\left(\mathrm{T}_{\mathrm{n}}\right)$ : Tumor weight of day 0 (day $\mathrm{n}$ ) in the treated group

\section{RESULTS}

\section{Maximum Tolerated Dose (MTD) Results}

The MTD experiment was carried out to determined to select the appropriate therapeutic data by measuring the body weight daily for 14 days following a single intraperitonial injection of TPTQ at various doses. The percentage weight loss was recorded. A weight loss of greater than $15 \%$ from initial dose was considered toxic. The MTD was the dose one step lower than the toxic dose. A dose of $800 \mathrm{mg} / \mathrm{kg}$ of TPTQ was selected as the MTD since caused weight loss near $15 \%$.

\section{In vivo Antitumor activity of TPTQ}

For in vivo antitumor study of TPTQ, NCI-H460 tumor cell line was selected on the basis of in vitro sensitivity. Female nude mice bearing NCI-H460 tumors at size approximately $5 \mathrm{~mm}$ in diameter were treated with a single intraperitoneal dose $800 \mathrm{mg} / \mathrm{kg}$ of TPTQ. The vehicle-treated (10\% Tween 80 ) animals were used as control group. The tumor size and mice body weight were measured for 14 days. Single treatment of 800 $\mathrm{mg} / \mathrm{kg}$ of TPTQ displayed moderate antitumor activity against NCIH460 tumor xenografts as compared with vehicle-treated control (Figure 2). Serial caliper measurements of perpendicular diameters were used to calculate tumor volume. Data are plotted as mean relative tumor volume $\left(\mathrm{mm}^{3}\right)$. The mean time to reach Relative Tumor Volume (RTV) of 4 for vehicle-treated control group was 5 days whereas for TPTQ treated $(800 \mathrm{mg} / \mathrm{kg}$ ) group was 10 days. Based on these observation, TPTQ slowed the tumor growth by 5 days. There is a significant difference in body weight in relation to treatment $(\mathrm{p}<0.05), \mathrm{r}^{2}=0.905$, which means $90.5 \%$ of the changes in body weight, can be explained by changes in treatment. The relationship between tumor size and treatment also had shown a significant difference $(\mathrm{p}<0.05)$, but $\mathrm{r}^{2}=0.147$ that means only $14.7 \%$ of the changes in tumor size can be explained by changes in treatment. Results were further analysed by Bonferroni, Dunnett, Tukey's, LSD and Duncan which confirmed association of body weight in control group and the treatment group, while less association was seen in tumor size between control and treatment group. While it had shown no significant difference and association of tumor size nor body weight with days (duration of treatment).

\section{DISCUSSION}

As shown in Figure 2, the tumor growth delay induced by $800 \mathrm{mg} / \mathrm{kg}$ of TPTQ was not statically significant from 0 day onwards to day 14 of treatment as compared with vehicle control group. However, no substantial body weight loss was observed in any groups through out the experi- 


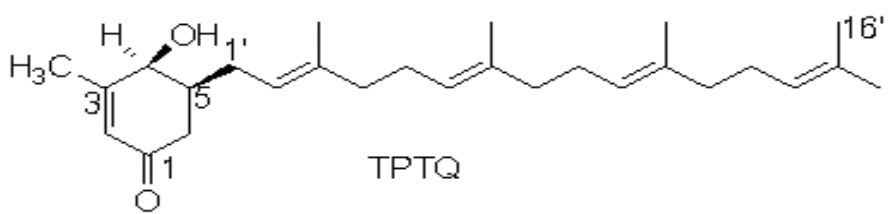

Figure 1: The structure of TPTQ.

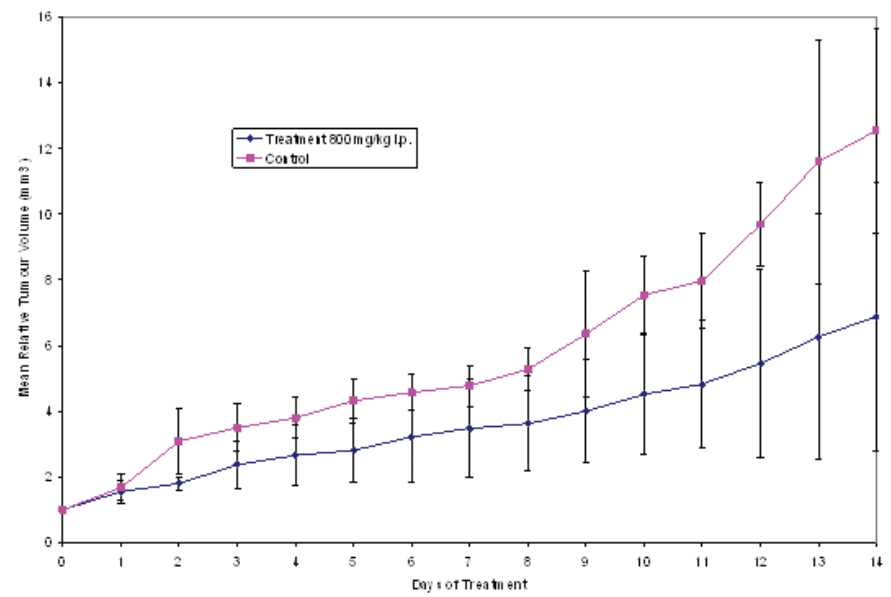

Figure 2: Antitumor effect of TPTQ on the growth of $\mathrm{H}-460$ xenografts in athymic nude mice. Female nude mice bearing established subcutaneous $\mathrm{H}-460$ tumors were treated with single intraperitoneal injections of TPTQ $(800 \mathrm{mg} / \mathrm{kg})$ or vehicle (10\% tween 80 ) for 14 days. Serial caliper measurements of perpendicular diameters were used to calculate tumor volume. Data are plotted as mean relative tumor volume, $\mathrm{mm}^{3} \pm S D(n=4)$.

ment. Mice receiving vehicle alone showed an increased in the body weight as compared with their initial body weights at the end of the treatment. Mice treated with $800 \mathrm{mg} / \mathrm{kg}$ showed a slight drop in their body weight, with maximum weight loss of $11.7 \%$ on day 1 . Therefore, based on the mean body weight changes, it can be concluded that no severe toxicity was observed in the experimental mice treated with TPTQ.

\section{CONCLUSION}

The tumor weights were measured and these values were converted to relative tumor volume (RTV). The RTV-time profile curves were constructed to determine the tumor growth delay as the antitumor activity parameter. TPTQ slowed the tumor growth by 5 days when RTV of 4 was considered without severe toxicity during the experiment.

From the data above, TPTQ could be the most promising lead to be developed into anticancer drug. This compound demonstrated in vitro selective cytotoxic agent against $\mathrm{H}-460$ cancer cell lines. The cytotoxic activity of this compound was supported by its in vivo tumor growth inhibition in H-460 tumor xenografted nude mice. From this study, it is proposed that the antitumor activities of TPTQ are by inhibit cell growth by inducing $\mathrm{G}_{1}$ phase cell cycle arrest as well as apoptotic cell elimination. ${ }^{8}$

\section{ACKNOWLEDGEMENT}

The author thank the Malaysian Ministry of Science, Technology and the Environment are thanked for financial support under the Intensified Research in Priority Areas Research Grant (IRPA, EAR No. 09-02-040313), International Foundation for Science (IFS no F/3967-1), National L'Oreal Fellowship Grant.

\section{CONFLICT OF INTEREST}

We do not have conflict on interest.

\section{ABBREVIATION USED}

TPTQ: Tetraprenyltoluquinone; RTV: Relative tumor volume; DMEM: Dulbecco's Modified Eagle's_ Medium; PBS: Phosphate buffered saline; FBS: fetal bovine serum; RNase A: ribonuclease A; DMSO: Dimethylsulfoxide; MTT: 3-(4,5dimethylthiazol-2yl)- diphenyltetrazolium bromide; EDTA: Ethylene diamine tetraacetate; MTD: Maximum Tolerance Dose; I.P: Intra peritonial.

\section{REFERENCES}

1. Zhang B, Liu ZM, Hao FG, Wang M. siRNA-directed cluster in silencing promotes cisplatin antitumor activity in human non-small cell lung cancer xenografts in immunodeficient mice. Eur Rev Med Pharmacol Sci. 2014;18(11):1595-601.

2. Cheng TYD, Cramb SM, Baade PD, Youlden DR, Nwogu C, Reid ME. The International Epidemiology of Lung Cancer: Latest Trends, Disparities, and Tumor Characteristics. J Thorac Oncol. 2016;11(10):1653-71.

3. Tsao AS, Scagliotti GV, Bunn Jr PA, et al. Scientific Advances in Lung Cancer 2015. J Thorac Oncol. 2016;11(5):613-38.

4. Shaikh AM, Shrivastava B, Apte KG, Navale SD. Medicinal Plants as Potential Source of Anticancer Agents: A Review. J Pharmacog Phytochem. 2016;5(2):291-5

5. Whitmore TC. Tree flora of Malaya. A manual for foresters vol. 2. Forest Department Ministry of Primary Industries Malaysia. Longman group Limited, London, $1973,208$.

6. Mahabusarakam W, Chairerk P, Taylor WC. Xanthones from Garcinia cowa Roxb. Latex. Phytochem. 2005;66:1148-53.

7. Panthong K, Hutadilok-Towatana N, Panthong A. Cowaxanthone F, a new tetraoxygenated xanthone, and other anti-inflammatory and antioxidant compounds from Garcinia cowa. Can J Chem. 2009;87:1636-40.

8. Ritthiwigrom T, Laphookhieo S, Pyne SG. Chemical constituents and biological activities of Garcinia cowa Roxb. Maejo Int J Sci Technol. 2013;7(02):212-31

9. Husni E, Nahari F, Wirasti Y, Wahyuni FS, Dachriyanus. Cytotoxicity study of ethanol extract of the stem bark of asam kandis (Garcinia cowa Roxb.) on T47D. Asian Pac J Trop Biomed. 2015;5(3):249-52.

10. Wahyuni FS, Shaari K, Stanslas J, Lajis NH, Dachriyanus. Cytotoxic xanthones from the stem bark of Garcinia cowa Roxb. J Chem Pharm Res. 2015;7(1):227-36.

11. Wahyuni FS, Lindsay TB, Dachriyanus, Dianita R, Jubahar J, Lajis NH, et al. A new ring-reduced tetraprenyltoluquinone and a prenylated xanthone from Garcinia cowa. Aust J Chem. 2005;57(3):223-6.

12. Wahyuni FS, Shaari K, Stanslas J, Lajis NH, Dachriyanus. Cytotoxic Studies of Tetraprenyltoluquinone, A Prenylated Hydroquinone From Garcinia Cowa on H-46-, MCF-7 and DU-145. Int J Pharm Pharm Sci. 2015;7(3):60-3.

13. Wahyuni FS, Hui LS, Stanslas J, Lajis NH, Dachriyanus. Tetraprenyltoluquinone, an Anticancer Compound from Garcinia cowa Roxb Induce Cell Cycle Arrest on H460 Non Small Lung Cancer Cell Line. Int J Pharm Sci Rev Res. 2015;32(2):166-8.

14. Stanslas J, Hagan DJ, Ellis MJ, Turner C, Carmicheal J, Ward W, et al. Antitumor polycyclic acridine. 7. Synthesis and biological properties of DNA affinic tetra and penta cyclic acridine. J Med Chem. 2000;43(8):1563-72.

Article History: Submission Date: 07-11-16; Received Date: 26-12-16; Acceptance Date: 28-12-16

Cite this article: Wahyuni FS, Hui LS, Stanslas J, Lajis NH, Dachriyanus. In vivo study of tetraprenyltoluquinone, an anticancer compounds from Garcinia cowa Roxb. J Young Pharm. 2017;9(2):296-8. 